\title{
Farklı Ekim Zamanlarının Soya Fasulyesi Çeşitlerinde Bazı Tarımsal Özellikler Üzerine Etkileri
}

\author{
Effects of Different Sowing Times on Some Agricultural Properties in Soybean Varieties
}

\author{
Melih OKCU ${ }^{1 *}$ \\ ${ }^{1}$ Atatürk Üniversitesi, Ziraat Fakültesi, Tarla Bitkileri Bölümü, 25200, Erzurum
}

• Geliş tarihi / Received: 14.05.2020 •Düzeltilerek geliş tarihi / Received in revised form: 11.08.2020 • Kabul tarihi / Accepted: 13.08 .2020

$\ddot{O} \mathbf{z}$

$\mathrm{Bu}$ araştırma farklı ekim zamanı uygulamalarının farklı soya fasulyesi çeşitlerinde bazı tarımsal özellikler üzerine etkilerini belirlemek amacıyla Gümüşhane Üniversitesi Gümüşhane Meslek Yüksekokulu deneme alanında 2014 ve 2015 yıllarında yürütülmüştür. Deneme, Şansa Bağlı Tam Bloklar deneme planına göre 3 tekrarlamalı olarak kurulmuş, Nova, SA-88, Ataem-7, Bravo, A-3127, Arısoy, Yeşilsoy ve Yemsoy çeşitleri kullanılmış ve 3 farklı ekim zamanında (1 Nisan, 15 Nisan ve 30 Nisan) ekim yapılmıştır. En yüksek tohum verimi her iki yılda da sırasıyla $202.24(\mathrm{~kg} / \mathrm{da}), 210$ (kg/da) ile Yemsoy çeşidinden, en düşük değer ise 2014 yllında 68.40 (kg/da) ile Bravo çeşidinden, 2015 yılında ise 120 (kg/da) ile Ataem-7 çeşidinden elde edilmiştir. Gümüşhane ekolojik şartlarında 1 Nisan tarihinin en uygun ekim tarihi olduğu tespit edilmiştir.

Anahtar kelimeler: Ekim Zamanı, Glycine max.L. Soya Fasulyesi, Tohum Verimi

\begin{abstract}
This research was conducted in 2014 and 2015 in the experimental field of Gumushane University Gumushane Vocational School in order to determine the effects of different sowing time applications on some agricultural characteristics in different soybean varieties. The research was carried out in 3 replications according to the exact blocks trial pattern of chance. In the research Nova, SA-88, Ataem-7, Bravo, A-3127, Artsoy, Yeşilsoy and Yemsoy varieties were used and on 3 different planting times (1 April, 15 April and 30 April) sowing has been done. The highest seed yield is from Yemsoy variety with $202.24(\mathrm{~kg} / \mathrm{da}), 210$ ( $\mathrm{kg} / \mathrm{da}$ ) respectively, the lowest value is from Bravo variety with $68.40(\mathrm{~kg} / \mathrm{da})$ in 2014, and $120(\mathrm{~kg})$ in 2015. / da and Ataem-7 cultivar. It is determined that April 1 is the most suitable planting date in Gümüşhane ecological conditions.
\end{abstract}

Keywords: Sowing Date, Glycine max.L., Soyabean, Seed Yield

*aa Melih OKCU; melihokcu@atauni.edu.tr, Tel: (0442)231 24 03, orcid.org/0000-0001-5213-2169 


\section{Giriş}

Tohumlarında ortalama \%36-40 protein, \%26 karbonhidrat, \%18-24 yağ ve \%8 oranında madensel maddeleri bulunduran soya, baklagiller familyasından olup tek y1llık, yazlık bir bitkidir. Oldukça yüksek protein kalitesine sahip olan soya, hayvansal proteine çok yakın olup gelişme ve büyümeye katkı sunan ve hızlandıran çok kıymetli amino asitler içerdiğinden dolayı, farklı kullanım alanlarında değerlendirilmektedir (Bellaloui vd., 2013, Bohn vd., 2014). Dünya'da birim alanda en çok protein üreten bitki konumunda olan soya, tohumlarından yağı alındıktan sonra geriye kalan küspesi bol miktarda protein içerdiğinden, iyi bir hayvan yemi olarak, özellikle kanatl yem rasyonlarında yüksek oranda kullanılmakta ve yeşil gübre olarak da değerlendirilmektedir (Okcu vd., 2007).

Diğer bitkisel ve hayvansal yem kaynaklarına göre, birim alandan daha fazla ve ucuz protein sağlaması, soyanın en önemli özelliğini oluşturmaktadır. Soya günümüzde düşük maliyeti ve zengin besin içeriği ile gida ürünlerinin üretiminde süt, yumurta ve et proteini yerine tercih edilmektedir (Ali, 2010).

Soya üretimini sınırlayan pek çok faktör vardır. $\mathrm{Bu}$ faktörler arasında uygun olmayan ekim zamanı, iklim değişikliği, düşük çimlenme oranı, zayıf tohum kalitesi ve nem stresi bulunmaktadır. $\mathrm{Bu}$ faktörler arasında ekim zamanı ve bitki yoğunlukları soya fasulyesinin büyüme ve gelişmesini, tane verimini (Zhang vd., 2010) ve tohum kalitesini etkileyen en önemli faktörlerdir (Rahman vd., 2005). Soya fasulyesi çeşitlerini ve agronomik kusurları keşfetmek, bu açı̆̆ kapatmamıza yardımcı olabilir.

Ekim zamanı, ürün verimi üzerine çok fazla etki yapan değişkendir (Calvino vd., 2003a, b), ve soya üretiminin en etkili kültürel uygulamalarından biridir (Robinson vd., 2009). Aynı zamanda hem ekonomik olması hem de ürün verimini artırması bakımından ekim zamanı, soya için iyi bir yaklaşımdır (Hoeft vd., 2000; Naeve vd., 2004).

Farklı ekim zamanlarında yapılan ekimler, ürün dönüşümü sırasında farklı etmenlerden dolayı soyanın gelişim aşamalarını etkiler. $\mathrm{Bu}$ etmenler fotoperyottaki varyasyon, (Han vd., 2006; Kumudini vd., 2007), hava sicaklığı (Chen ve Wiatrak, 2010), yağış dağılımı ve miktarı (Hu ve Wiatrak, 2012)'dır. Ekim zamanı soya fasulyesinin verim ve gelişmesine önemli ölçüde etkiye sahiptir. Mevsimde erken ekim, zayıf çıkışa ya da sınırlı bir büyümeye sebep olabilir. Ürün yüksek sıcaklığa maruz kaldığında, kritik uzunluktan daha kısa bir günde hızlı bir şekilde olgunlaşabilir. Eğer bu olay, bitki yeterli bir boyuta ulaşmadan gerçekleşirse, soya fasulyesi düşük verim verir ve bodur kalır (Boquet ve Clawson, 2007). Ancak geç ekim, vejatatif safhayı küçültebilir, bu da kuru madde birikimini azaltarak, üreme parçalarına zayıf bölünmelere ve sonuçta potansiyel verimin düşük gerçekleşmesine neden olur (Ram vd., 2010).

$\mathrm{Bu}$ çalışma, Gümüşhane ekolojik şartlarında farklı ekim zamanlarının soya fasulyesi çeşitlerinde bazı tarımsal özelliklerini belirlemek amacıyla yürütülmüştür.

\section{Materyal ve Metot}

Denemede Karadeniz Tarımsal Araştırma Enstitüsü Müdürlüğünden 6 (NOVA, ARISOY, A3127, SA-88, ATAEM-7, BRAVO), Doğu Akdeniz Tarımsal Araştırma Enstitüsü Müdürlügü̈nden temin edilen 2 soya (Yemsoy, Yeşilsoy) çeşidi olmak üzere toplam 8 soya çeşidi kullanılmıştır. Bitki besin elementi ihtiyacını karşılamak amacıyla amonyum sülfat (\%21), triple süperfosfat $(\% 45)$, potasyum sülfat $(\% 48)$ ve ayrıca soya bakteri kültürü (Rhizobium Japonicum) kullanılmıştır.

Araştırma Gümüşhane Üniversitesi Gümüşhane Meslek Yüksekokulu deneme alanında 2014-2015 yıllarında yürütülmüştür. Araştırma 8 çeşit (NOVA, ARISOY, A-3127, SA-88, ATAEM-7, BRAVO, YEŞILLSOY, YEMSOY) ve 3 değişik ekim zamanının (1 Nisan-15 Nisan- 30 Nisan) yer aldığ 8 x 3 şeklindeki bu faktöriyel düzenleme, Şansa Bağlı Tam Bloklar deneme planına göre 3 tekrarlı toplam 72 parsel şeklinde düzenlenmiştir (Y1ld1z,1994). Parsel alan1 $2.8 \mathrm{~m}$ x $6.0 \mathrm{~m}=16.8$ $\mathrm{m}^{2}$ 'dir. Parseller arasinda $1.5 \mathrm{~m}$ bloklar arasinda 2.5 m'lik mesafe bırakılmıştır. Deneme parselleri 4 sıradan oluşmuştur. Dekara $3 \mathrm{~kg} \mathrm{~N}, 6 \mathrm{~kg} \mathrm{P}_{2} \mathrm{O}_{5}$ ve 8 $\mathrm{kg} \quad \mathrm{K}_{2} \mathrm{O}$ gübre ekim sirasında verilmiştir (İlisulu,1973). Deneme alanında bakım işlemleri yapılmış, bitkiler 8-10 cm olduğunda yabancı otlar elle veya çapa ile uzaklaştırılmıştır.

Ortalama sıcaklık 2015 yılında Şubat ve Kasım ayları arasında $0^{\circ} \mathrm{C}$ 'nin altına düşmezken, 2014 yılında $0^{\circ} \mathrm{C}$ 'nin altına hiç düşmemiştir. Uzun yıllar ortalamasında en yüksek sicaklık Temmuz ayında $\left(20.20{ }^{\circ} \mathrm{C}\right)$ ile gerçekleşirken, araştırmanın yürütüldüğü yıllarda en yüksek sicaklık Ağustos aylarında sirasıyla 23.0 ve $22.8{ }^{\circ} \mathrm{C}$ ve yine uzun yıllar ortalamasında en düşük sicaklık Ocak ayında $-1,7^{\circ} \mathrm{C}$ olurken, araştırmanın yürütüldüğü yıllarda ise en düşük sıcaklık Ocak ayında 0.8 ve $-0.6{ }^{\circ} \mathrm{C}$ 
olarak tespit edilmiştir. En fazla yağış 2014 yılında Mayıs ayında $66.7 \mathrm{~mm}, 2015$ yilında ise Mart ayında $67.4 \mathrm{~mm}$ gerçekleşmiştir. Uzun yıllarda ise en fazla yağış Mayıs $(65.8 \mathrm{~mm})$, en düşük ise
Ağustos ayında (12.1 mm) gerçekleşmiştir (Tablo $1)$.

Tablo 1. Gümüşhane ili uzun yıllar ortalaması (1960-2015) ve Araştırma yıllarına ait iklim verileri

\begin{tabular}{|c|c|c|c|c|c|c|c|c|c|c|}
\hline \multirow[b]{2}{*}{ Aylar } & \multicolumn{3}{|l|}{2014} & \multicolumn{3}{|l|}{2015} & \multicolumn{4}{|c|}{1960 - 2015 uzun yillar ortalamas 1} \\
\hline & \begin{tabular}{|l|} 
Aylık \\
Toplam \\
Yağış \\
$(\mathrm{mm})$
\end{tabular} & \begin{tabular}{|l} 
Aylik \\
Ortalama \\
Sicaklık \\
$\left(\mathrm{C}^{0}\right)$
\end{tabular} & \begin{tabular}{|l|} 
Aylik \\
Ortalama \\
Nispi \\
Nem \\
$(\%)$
\end{tabular} & $\begin{array}{l}\text { Aylık } \\
\text { Toplam } \\
\text { Yağış } \\
(\mathrm{mm})\end{array}$ & \begin{tabular}{|l} 
Aylık \\
Ortalama \\
Sicaklık \\
$\left(\mathrm{C}^{0}\right)$
\end{tabular} & \begin{tabular}{|l|} 
Aylık \\
Ortalama \\
Nispi \\
Nem \\
$(\%)$
\end{tabular} & \begin{tabular}{|l|} 
Sicaklik \\
Ortalamas1 \\
$\left(\mathrm{C}^{0}\right)$
\end{tabular} & $\begin{array}{l}\text { Güneşlenme } \\
\text { Gün Süresi }\end{array}$ & $\begin{array}{l}\text { Nispi } \\
\text { Nem }\end{array}$ & $\begin{array}{l}\text { Ortalama } \\
\text { Toplam } \\
\text { Yağış } \\
(\mathrm{mm})\end{array}$ \\
\hline OCAK & 28.5 & 0.8 & 59.1 & 55.5 & -0.6 & 58.3 & -1.7 & 1.20 & 68.5 & 35.2 \\
\hline SSUBAT & 22.1 & 2.5 & 45.6 & 34.4 & 2.2 & 55.8 & -0.5 & 3.46 & 65.7 & 32.2 \\
\hline MART & 45.3 & 6.5 & 46.8 & 67.4 & 5.5 & 50.4 & 3.7 & 5.02 & 63.5 & 41.8 \\
\hline NISAN & 38.1 & 11.3 & 46.4 & 46.8 & 7.5 & 49.4 & 9.4 & 6.06 & 61.5 & 60.3 \\
\hline MAYIS & 66.7 & 14.7 & 52.4 & 45.3 & 13.8 & 49.9 & 13.7 & 7.30 & 62.3 & 65.8 \\
\hline HAZİRAN & 31.0 & 17.8 & 44.1 & 40.6 & 17.9 & 52.3 & 17.2 & 9.12 & 61.1 & 44.3 \\
\hline TEMMUZ & 19.3 & 21.7 & 36.7 & 2.8 & 20.9 & 38.7 & 20.2 & 10.04 & 60.2 & 12.7 \\
\hline AĞUSTOS & 12.4 & 23.0 & 34.9 & 5.7 & 22.8 & 42.2 & 20.1 & 9.46 & 60.5 & 12.1 \\
\hline EYLÜL & 51.5 & 17.6 & 43.1 & \begin{tabular}{|l|}
9.6 \\
\end{tabular} & \begin{tabular}{|l|}
20.7 \\
\end{tabular} & 36.8 & \begin{tabular}{|l|}
16.6 \\
\end{tabular} & \begin{tabular}{|l|}
8.59 \\
\end{tabular} & 60.5 & 19.7 \\
\hline EKIM & 61.4 & 11.5 & 54.1 & \begin{tabular}{|l|}
50.1 \\
\end{tabular} & 12.5 & 55.8 & \begin{tabular}{|l|}
11.4 \\
\end{tabular} & 5.33 & \begin{tabular}{|l|}
64.7 \\
\end{tabular} & 42.0 \\
\hline KASIM & 51.6 & 4.9 & 55.0 & 79.4 & 6.0 & 52.4 & 5.1 & 2.12 & 68.3 & 41.1 \\
\hline ARALIK & 14.2 & 4.9 & 58.6 & 31.7 & \begin{tabular}{|l|}
-1.9 \\
\end{tabular} & 64.9 & \begin{tabular}{|l|}
0.4 \\
\end{tabular} & \begin{tabular}{|l|}
0.51 \\
\end{tabular} & \begin{tabular}{|l|}
69.7 \\
\end{tabular} & 39.9 \\
\hline Ortalama & 36.84 & 11.43 & 48.07 & 39.10 & \begin{tabular}{|l|}
10.53 \\
\end{tabular} & 50.57 & \begin{tabular}{|l|}
10.00 \\
\end{tabular} & \begin{tabular}{|l|}
5.68 \\
\end{tabular} & 63.87 & 33.79 \\
\hline
\end{tabular}

Tablo 2. Deneme alanına ait toprak parametreleri

\begin{tabular}{cccccccc}
\hline Saturasyon (\%) & $\mathbf{p H}$ & $\begin{array}{c}\mathbf{E C} \\
(\mathbf{d s} / \mathbf{m})\end{array}$ & $\begin{array}{c}\text { Tuz } \\
(\boldsymbol{\%})\end{array}$ & $\begin{array}{c}\text { Kireç } \\
(\boldsymbol{\%})\end{array}$ & $\begin{array}{c}\text { Organik } \\
\text { Madde(\%) }\end{array}$ & $\begin{array}{c}\mathbf{P}_{2} \mathbf{O}_{5} \\
(\mathbf{k g} / \mathbf{d a})\end{array}$ & $\begin{array}{c}\mathbf{K}_{2} \mathbf{O} \\
(\mathbf{k g} / \mathbf{d a})\end{array}$ \\
\hline 44.0 & 7.44 & 1.48 & 0.04 & 0.99 & 2.21 & 1.52 & 32 \\
\hline
\end{tabular}

Tablo 2'de görüldüğg̈ gibi, toprak analizlerine göre deneme topraklarının saturasyon değeri \%44'tür. Ayrıca deneme sahasi topraklarında toplam tuz $\% 0.04, \mathrm{pH}$ değeri 7.44 , kireç $\% 0.99$, organik madde \%2.21, bitkilere yarayışlı $\mathrm{P}_{2} \mathrm{O}_{5} 1.52 \mathrm{~kg} / \mathrm{da}$, $\mathrm{K}_{2} \mathrm{O} 32 \mathrm{~kg} / \mathrm{da}$ 'dır. Bu verilere göre deneme sahas 1 toprakları tuzsuz, hafif alkali karakterde, kireçli, bitkilere yarayışlı fosfor az, potasyum bakımından da az ve organik maddece zengin durumdadır (Sezen, 1991). Sonuçların varyans analizi şansa bağl1 tam bloklar deneme desenine göre SPSS 20.0 paket programı (SPSS INC, 2010) yardımıyla yapılmıştır. Duncan çoklu karşılaştırma testi ile ortalamalar arasındaki farklılıklar tespit edilmiştir (Yıldız ve Bircan,1994).

\section{Bulgular ve Tartışma}

Bitki boyu ürünün büyümesi ve fenolojisini belirtir. Bitki boyu verilerinin istatistiki analiz sonuçlarına göre çeşitler, ekim zamanları arasında \%1 seviyesinde, çeşit x ekim zamanı; ekim zamanı $\mathrm{x}$ yıl ve çeşit $\mathrm{x}$ ekim zamanı $\mathrm{x}$ yıl uygulaması interaksiyonlarında ise $\% 5$ seviyesinde fark tespit edilmiştir (Tablo 3.). Farklı ekim zamanlarının ve çeşitlerinin bitki boyuna ve çeşitler üzerine etkisi önemli çıkmıştır (Tablo 3.). 1 Nisan tarihli ekim $96.80 \mathrm{~cm}$ ile en yüksek bitki boyu ile diğer uygulamaların üzerinde yer almıştır. Çeşitlerin ortalamasına bakıldığında 8 çeşit arasında en uzun bitki boyu $113.93 \mathrm{~cm}$ ile Yeşilsoy çeşidinde, en kısa ise $70.07 \mathrm{~cm}$ ile Bravo çeşidinde ölçülmüştür. (Tablo 3). En yüksek bitki boyu Birinci ekim zamanı olan 1 Nisan tarihinde optimum çevre şartları ile birlikte oldukça uzun büyüme peryodunun olması bitki boyunun daha uzun olmasına neden olmuştur. Bu sonuçlar, fotoperyot duyarlılığının geç ekim nedeniyle büyüme döneminde belirgin bir azalma olduğunu belirten Wade ve Johnston (1975) ile uyumludur. Ayn zamanda Ram vd., (2010) yapmış olduğu araştırmada, soyada 3 farklı ekim zamanı içerisinde en yüksek bitki boyunu $85.7 \mathrm{~cm}$ ile 5 Haziran tarihli ekimden ve çeşitler bakımından ise en yüksek bitki boyunu $84.5 \mathrm{~cm}$ ile SL 744 çeşidinin verdiğini bildirmişlerdir. Rehman vd., (2014) ise 5 farklı ekim zamanı uyguladıkları çalışmalarında en yüksek bitki boyunu $96.23 \mathrm{~cm}$ ile 28 Ocak tarihli ekimden elde etmiştir. Aynı çalışmada en yüksek bitki boyu $80.83 \mathrm{~cm}$ ile Faisal çeşidinden elde 
edilmiştir. Ngalamu vd., (2012) yapmış olduğu çalışmada, en yüksek bitki boyunu $40.3 \mathrm{~cm}$ ile TGx 1740-2F genotipinden elde etmiştir. Kang vd., (2017) bitki boyunu $79 \mathrm{~cm}$ ile Uram genotipinden elde ettiğini bildirmiştir. Çalışmamızdan elde edilen sonuçlar, Boydak vd., 2018 ile benzerlik gösterirken; Ram vd., (2010), Ngalamu vd., (2012), Doğan vd., 2015; Rehman vd., (2014) ve Kang vd., (2017)'nin değerlerinden ise yükssek çıkmıştır.

Dal sayısına ait varyans analiz sonuçlarına göre çeşitler \%1 seviyesinde, çeşit x ekim zamanı; çeşit $\mathrm{x}$ yıl; ekim zamanı $\mathrm{x}$ yıl ve çeşit $\mathrm{x}$ ekim zamanı $\mathrm{x}$ y1l uygulaması interaksiyonları ise $\% 5$ seviyesinde önemli bulunmuştur. Dal sayısı incelendiğinde en fazla dal sayısı 1.94 adet ile Arısoy çeşidinden elde edilmiştir. Ekim zamanı uygulamalarında ise 1 Nisan uygulaması 1.56 adet ile diğer uygulamalar arasında en yüksek değeri vermiştir. (Tablo 3.). Çeşitler arasında dal sayısı bakımından farklar genotipik özelliklerden ve değişik çevre koşullarından farklı şekilde etkilenmelerinden kaynaklandığı düşünülmektedir. Çeşitler arasında dal sayısı bakımından farklılık önemli bulunurken, ekim zamanları açısından herhangi bir farklılık bulunamamıştır (Tablo.3). Ngalamu vd., (2012) yapmış olduğu çalışmada, dal sayısını 4.6 adet ile TGx 1937-1F genotipinden elde etmiştir. Kang vd., (2017) dal sayısin 3.1 adet ile Uram genotipinden elde ettiğini bildirmiştir. Elde ettiğimiz bulgular Yaver ve Paşa (2009), Kınacı (2011) ve Boydak vd., (2018)'in elde ettiği bulgular dan düşük çıkmıştır.

Sadeghi ve Niyaki (2013) geç ekimin daha az vejetatif gelişim, kısa sap ve düşük üretici nodüllere sebep olduğunu bildirmişlerdir. Whigham ve Minor (1978) soya varyetelerinin gün uzunluğuna verdikleri cevabın farklı olduğunu ifade etmiştir. Uzun gün süresindeki farkl1l1klar çiçeklenme gün, olgunlaşma gün, bakla, dal ve nodül sayısına, bitki boyu ve tohum ağırlıklarına verdikleri cevapla sonuçlanır. Whigham ve Minor (1978) ve Sadeghi ve Niyaki (2013)'ün bildirdiği gibi soya kısa gün bitkisi olduğundan dolayı, kısa gün şartlarında uzun gün şartlarından daha az vejetatif gelişim üretir. Hu ve Wiatrak (2012) geç ekim ve olumsuz çevre şartlarının soyada büyüme, gelişme ve verim üzerine negatif etkiye sahip olduğunu bildirmişlerdir. Geç ekimle birlikte fotoperyot ve sicaklıktaki değişiklikler bitki boyu, bakla, dal sayısı üreme ve vejetasyon süresini etkiler.

İlk bakla yüksekliği en yüksek değer $24.05 \mathrm{~cm}$ ile Yeşilsoy çeşidinden elde edilirken, onu $21.62 \mathrm{~cm}$ ile Yemsoy çeşidi takip etmiştir. Ekim zamanı açısından 30 Nisan tarihli uygulamadan $(22.43 \mathrm{~cm})$ en yüksek değer elde edilmiştir (Tablo 3.). Çeşitler, ekim zamanları, yıl, çeşit x yıl; ekim zamanı x yıl bakımından istatistiki fark önemsiz bulunurken, çeşit x ekim zamanı; çeşit $\mathrm{x}$ ekim zamanı x yıl uygulamas1 interaksiyonları $\% 5$ seviyesinde önemli bulunmuştur (Tablo 3.). Ngalamu vd., (2012) yapmış olduğu çalışmada, ilk bakla yüksekliğini $6.8 \mathrm{~cm}$ ile TGx 1740-2F genotipinden elde etmiştir. Kang vd., (2017) ilk bakla yüksekliğini $19 \mathrm{~cm}$ ile Uram genotipinden elde ettiğini bildirmiştir. Elde ettiğimiz sonuçlar 4.3-9.4 cm Yilmaz vd., (2005) ve 10.17-19.50 cm Erdoğmuş vd., (2007); 9.8-16.1 cm, ile Doğan vd., (2015)'in değerlerinden yüksek bulunurken; 13.66$40.30 \mathrm{~cm}$ Boydak vd., (2018)'in çalışmasından düşük çıkmıştır. Çalışmalarda ortaya çıkan bu farklılığın ekolojik şartlardan ve genotiplerden kaynaklandığı düşünülmektedir.

İlk bakla yüksekliği soya yetiştiriciliğinde önem taşıyan bir konudur ve makinalı hasatta, hasat kaybının minimuma indirilebilmesi açısından ilk baklanın yüksekte olması önemlidir (Gizlenci vd., 2005). İlk bakla yüksekliği, bitki boyu ile pozitif ilişkidedir fakat; tohum ağırlığı, bakla başına tohum sayısı, bitki başına tohum sayısı ve bakla sayısı ile negatif ilişkidedir ( $\mathrm{Oz}$ vd., 2009). Bir başka çalışmada ise bitki boyu, boğum sayısı ve sap çapının diğerleriyle pozitif ilişkide olduğu bildirilmiştir (Ramteke vd., 2012). Ancak ilk bakla yüksekliğinin; bakla sayısının azalmış olabileceği ve bitki boyunun ilk bakla yüksekliğine oranının yüksek olmasından dolayı tohum verimiyle negatif ilişkide bulunduğu bildirilmiştir (Ghodrati vd.,2013).

Bakla sayısı bakımından çeşitler arasında fark önemli bulunmuştur. 2014 yilında en yüksek bakla sayıs1 84.80 adet bitki ile Arısoy çeşidinde, 2015 y1lında ise 82.14 adet bitki ile Yeşilsoy çeşidinde tespit edilmiştir. İki yılın ortalamasında çeşitler bakımından en yüksek değer 74.47 adet/bitki ile Yemsoy çeşidinden elde edilmiştir. Ekim zamanı açısından 15 Nisan tarihli uygulamadan (62.02 adet/bitki) en yüksek değer elde edilmiştir (Tablo 3). Çeşitler \%1 seviyesinde çok önemli, yıl, çeşit $x$ ekim zamanı; çeşit x yıl; ekim zamanı x yıl; çeşit $\mathrm{x}$ ekim zamanı $\mathrm{x}$ y1l uygulaması interaksiyonları ise $\% 5$ seviyesinde önemli bulunmuştur (Tablo 3). 
Tablo 3. Farklı Ekim Zamanlarının Soya Çeşitleri Üzerine Bazı Tarımsal Özelliklerin Etkisi

\begin{tabular}{|c|c|c|c|c|c|c|c|c|c|c|}
\hline \multirow[t]{2}{*}{ Ekim Zamanı } & \multirow[t]{2}{*}{ Çeşitler } & \multicolumn{3}{|c|}{ Bitki Boyu (cm) } & \multicolumn{3}{|c|}{ Dal Sayısı (adet) } & \multicolumn{3}{|c|}{ İlk Bakla Yüksekliği (cm) } \\
\hline & & 2014 & 2015 & Ekim Zam.Ort. & 2014 & 2015 & Ekim Zam.Ort. & 2014 & 2015 & Ekim Zam.Ort. \\
\hline \multirow{9}{*}{$\begin{array}{l}Z \\
Z \\
\frac{a}{Z} \\
Z\end{array}$} & Nova & 80.40 & 116.80 & 98.60 & 1.26 & 1.42 & 1.34 & 16 & 18 & 17 \\
\hline & SA-88 & 95.40 & 79.20 & 87.30 & 1.79 & 2 & 1.89 & 10.24 & 12.40 & 11.32 \\
\hline & ATAEM-7 & 99 & 87.60 & 93.30 & 1.53 & 1.76 & 1.64 & 9.70 & 10.40 & 10.05 \\
\hline & A-3127 & 84 & 85 & 84.50 & 1.53 & 1.76 & 1.64 & 15.14 & 17.60 & 16.37 \\
\hline & Arisoy & 86 & 92 & 89 & 1.44 & 1.94 & 1.69 & 14.41 & 17.40 & 15.90 \\
\hline & Yeşilsoy & 123.60 & 126.80 & 125.20 & 1.22 & 1.5 & 1.36 & 24.94 & 27 & 25.97 \\
\hline & Yemsoy & 117.20 & 115 & 116.10 & 1.49 & 1.7 & 1.59 & 26.72 & 29.60 & 28.16 \\
\hline & Ortalama & 95.03 a & 98.58 a & $96.80 \mathrm{~A}$ & $1.43 \mathrm{a}$ & $1.69 \mathrm{~b}$ & 1.56 & $16.28 \mathrm{c}$ & $18.30 \mathrm{c}$ & 17.29 \\
\hline & & 2014 & 2015 & Ekim Zam.Ort.. & 2014 & 2015 & Ekim Zam.Ort. & 2014 & 2015 & Ekim Zam.Ort. \\
\hline \multirow{9}{*}{ 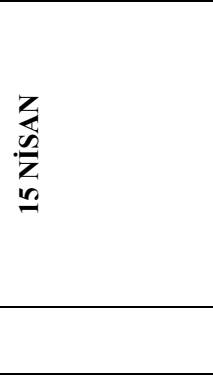 } & Nova & 78.20 & 86.20 & 82.20 & 1.83 & 1.92 & 1.88 & 11.25 & 13.40 & 12.33 \\
\hline & SA-88 & 100 & 95.20 & 86.70 & 1.48 & 1.66 & 1.57 & 20.14 & 23.20 & 21.67 \\
\hline & ATAEM-7 & 85.80 & 85.80 & 92.90 & 1.14 & 1.34 & 1.24 & 27.14 & 29.80 & 28.47 \\
\hline & Bravo & 66.60 & 66 & 75.90 & 1.01 & 1.04 & 1.02 & 18.11 & 22.40 & 20.26 \\
\hline & A-3127 & 76.60 & 72.60 & 69.60 & 1.12 & 1.36 & 1.24 & 12.01 & 14 & 13.01 \\
\hline & Arisoy & 89.40 & 83 & 79.80 & 1.21 & 1.56 & 1.39 & 19.15 & 21.40 & 20.27 \\
\hline & Yeşilsoy & 116.40 & 109 & 112.70 & 1.34 & 1.64 & 1.49 & 22.16 & 24.20 & 23.18 \\
\hline & Yemsoy & 93.40 & 83.40 & 88.40 & 1.28 & 1.50 & 1.39 & 13.03 & 14.20 & 13.61 \\
\hline & Ortalama & 86.90 b & $85.15 \mathrm{c}$ & $86.03 \mathrm{C}$ & $1.30 \mathrm{~b}$ & $1.50 \mathrm{c}$ & 1.40 & $17.87 \mathrm{~b}$ & $20.32 \mathrm{~b}$ & 19.10 \\
\hline \multirow{9}{*}{ 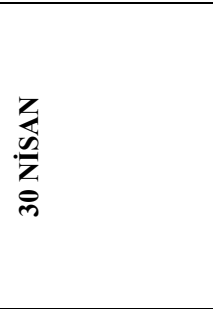 } & Nova & 100.40 & 85 & 92.70 & 1.43 & 1.50 & 1.46 & 13.80 & 15.20 & 14.50 \\
\hline & SA-88 & 87.20 & 71.60 & 79.40 & 1.01 & 1.30 & 1.15 & 23.94 & 26.40 & 25.17 \\
\hline & ATAEM-7 & 77.60 & 86.40 & 82 & 1.59 & 1.84 & 1.71 & 20.01 & 23.40 & 21.70 \\
\hline & Bravo & 69 & 93.40 & 81.20 & 1.24 & 1.52 & 1.38 & 22.40 & 25.20 & 23.80 \\
\hline & A-3127 & 74.40 & 87.40 & 80.90 & 1.24 & 1.52 & 1.38 & 21.78 & 24.40 & 23.09 \\
\hline & Arısoy & 93.20 & 103.40 & 98.30 & 1.33 & 1.62 & 1.47 & 23.45 & 26.80 & 25.12 \\
\hline & Yeşilsoy & 101.80 & 101.80 & 101.80 & 1.63 & 1.80 & 1.71 & 21.98 & 24 & 22.99 \\
\hline & Yemsoy & 101.80 & 113.60 & 107.70 & 1.58 & 1.76 & 1.67 & 21.96 & 24.20 & 23.08 \\
\hline & Ortalama & 88.18 b & $92.83 \mathrm{~b}$ & $90.50 \mathrm{~B}$ & $1.38 \mathrm{a}$ & $1.61 \mathrm{~b}$ & 1.49 & 21.16 a & 23.70 a & 22.43 \\
\hline \multirow{10}{*}{$\begin{array}{l}\text { ÇEŞiTLERIN } \\
\text { ORTALAMASI }\end{array}$} & Çeşitler & \multicolumn{3}{|c|}{ Bitki Boyu (cm) } & \multicolumn{3}{|c|}{ Dal Sayısı (adet) } & \multicolumn{3}{|c|}{ İlk Bakla Yüksekliği (cm) } \\
\hline & & 2014 & 2015 & Ort & 2014 & 2015 & Ort & 2014 & 2015 & Ort \\
\hline & Nova & $86.33 \mathbf{F}$ & $96 \mathrm{C}$ & 91.17 C & 1.51 & 1.61 & 1.56 & 13.68 & 15.53 & 14.61 \\
\hline & SA-88 & $94.20 \mathrm{C}$ & $82 \mathbf{F}$ & 88.10 CD & 1.43 & 1.65 & 1.54 & 18.11 & 20.66 & 19.39 \\
\hline & ATAEM-7 & $87.47 \mathbf{E}$ & $86,60 \mathbf{E}$ & $87.04 \mathrm{D}$ & 1.42 & 1.65 & 1.54 & 18.95 & 21.20 & 20.08 \\
\hline & Bravo & $70.07 \mathbf{H}$ & $81.87 \mathbf{F}$ & $75.97 \mathrm{~F}$ & 1.14 & 1.34 & 1.24 & 17.87 & 20.53 & 19.20 \\
\hline & A-3127 & $78.33 \mathbf{~ G}$ & $81.67 \mathbf{F}$ & $80 \mathrm{E}$ & 1.30 & 1.55 & 1.43 & 16.31 & 18.67 & 17.49 \\
\hline & Arisoy & $89,53 \mathbf{D}$ & $92.80 \mathrm{D}$ & $91,17 \mathrm{C}$ & 1.33 & 1.71 & 1.52 & 19 & 16.70 & 17.85 \\
\hline & Yeşilsoy & $113,93 \mathbf{A}$ & $112,53 \mathbf{A}$ & $113.23 \mathrm{~A}$ & 1.40 & 1.65 & 1.53 & 23.03 & 25.06 & 24.05 \\
\hline & Yemsoy & $104.13 \mathrm{~B}$ & $104 \mathbf{B}$ & 104,07 B & 1.45 & 1.65 & 1.55 & 20.57 & 22.67 & 21.62 \\
\hline \multicolumn{2}{|c|}{ Yilların Ortalaması } & 90.04 & 92.18 & 91.11 & 1.37 & 1.60 & 1.49 & 18.44 & 20.77 & 19.61 \\
\hline
\end{tabular}




\begin{tabular}{|c|c|c|c|c|c|c|c|c|c|c|}
\hline \multirow[t]{2}{*}{ Ekim Zamanı } & \multirow[t]{2}{*}{ Çeşitler } & \multicolumn{3}{|c|}{ Bakla Sayısı (adet/ bitki $^{-1}$ ) } & \multicolumn{3}{|c|}{ Bakla Başına Tohum Sayısı (adet/ bitki ${ }^{-1}$ ) } & \multicolumn{3}{|c|}{ Tohum Verimi (kg/da) } \\
\hline & & 2014 & 2015 & Ekim Zam.Ort. & 2014 & 2015 & Ekim Zam.Ort. & 2014 & 2015 & Ekim Zam.Ort. \\
\hline \multirow{11}{*}{ 文 } & Nova & 46.80 & 60.20 & 53.50 & 2.41 & 2.78 & 2.60 & 141.40 & 184 & 162.70 \\
\hline & SA- 88 & 65.20 & 60.26 & 62.73 & 2.40 & 2.65 & 2.53 & 118.60 & 146 & 132.30 \\
\hline & ATAEM-7 & 68.40 & 56.30 & 62.35 & 2.38 & 2.65 & 2.52 & 108.20 & 138 & 123.10 \\
\hline & Bravo & 48 & 56.20 & 52.10 & 2.30 & 2.55 & 2.43 & 129.60 & 131 & 130.30 \\
\hline & A-3127 & 53.20 & 61.10 & 57.15 & 2.43 & 2.52 & 2.48 & 138.40 & 146 & 142.20 \\
\hline & Arısoy & 40.60 & 80.10 & 60.35 & 2.38 & 2.44 & 2.41 & 108.60 & 142 & 125.30 \\
\hline & Yeşilsoy & 70.20 & 82.14 & 76.17 & 2.50 & 2.56 & 2.53 & 121.45 & 142 & 131.73 \\
\hline & Yemsoy & 52.06 & 53.20 & 52.63 & 2.60 & 2.64 & 2.62 & 198.22 & 210 & 204.11 \\
\hline & Ortalama & $55.56 \mathrm{a}$ & $63.69 \mathrm{~b}$ & 59.63 & $2.43 \mathrm{a}$ & $2.60 \mathrm{a}$ & 2.52 & $133.06 \mathrm{~A}$ & $154.90 \mathrm{~A}$ & 143.97 A \\
\hline & Çeşitler & \multicolumn{3}{|c|}{ Bakla Sayısı (adet/ bitki $^{-1}$ ) } & \multicolumn{3}{|c|}{ Bakla Bașına Tohum Sayısı (adet/ bitki ${ }^{-1}$ ) } & \multicolumn{3}{|c|}{ Tohum Verimi (kg/da) } \\
\hline & & 2014 & 2015 & Ekim Zam.Ort. & 2014 & 2015 & Ekim Zam.Ort. & 2014 & 2015 & Ekim Zam.Ort. \\
\hline \multirow{11}{*}{ 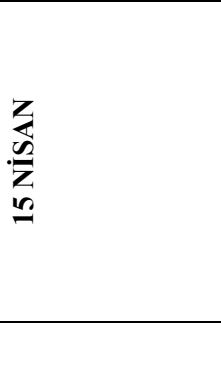 } & Nova & 53.40 & 61.25 & 57.33 & 1.99 & 2.70 & 2.35 & 84.40 & 172 & 128.20 \\
\hline & SA-88 & 58.60 & 58.24 & 58.42 & 2.01 & 2.57 & 2.29 & 128 & 134 & 131 \\
\hline & ATAEM-7 & 67.20 & 58.10 & 62.65 & 2.08 & 2.52 & 2.30 & 115.80 & 124 & 119.90 \\
\hline & Bravo & 46.40 & 58.25 & 52.33 & 2.03 & 2.44 & 2.24 & 68.40 & 121 & 94.70 \\
\hline & A-3127 & 53.20 & 58.15 & 55.68 & 2.34 & 2.48 & 2.41 & 111.60 & 134 & 122.80 \\
\hline & Arısoy & 84.80 & 76.70 & 80.75 & 2.46 & 2.40 & 2.43 & 138.60 & 134 & 136.30 \\
\hline & Yeşilsoy & 72.10 & 80.10 & 76.10 & 2.56 & 2.50 & 2.53 & 138.97 & 132 & 135.50 \\
\hline & Yemsoy & 53.65 & 52.10 & 52.88 & 2.53 & 2.60 & 2.57 & 202.24 & 191 & 196.62 \\
\hline & Ortalama & $61.17 \mathbf{a}$ & $62.86 \mathrm{ab}$ & 62.02 & $2.25 \mathrm{c}$ & $2.53 \mathrm{c}$ & 2.39 & $123.50 \mathrm{~B}$ & $142.75 \mathrm{C}$ & 133.13 B \\
\hline & Çeşitler & \multicolumn{3}{|c|}{ Bakla Sayısı (adet/ bitki $\left.^{-1}\right)$} & \multicolumn{3}{|c|}{ Bakla Başına Tohum Sayısı (adet/ bitki $^{-1}$ ) } & \multicolumn{3}{|c|}{ Tohum Verimi (kg/da) } \\
\hline & & 2014 & 2015 & Ekim Zam.Ort. & 2014 & 2015 & Ekim Zam.Ort. & 2014 & 2015 & Ekim Zam.Ort. \\
\hline \multirow{9}{*}{ 吕 } & Nova & 55.60 & 60.05 & 57.83 & 2.11 & 2.73 & 2.42 & 89.80 & 176 & 132.90 \\
\hline & SA-88 & 43.20 & 60.44 & 51.82 & 3.33 & 2.68 & 3.01 & 80.20 & 140 & 110.10 \\
\hline & ATAEM-7 & 53.60 & 61.20 & 57.40 & 2.18 & 2.55 & 2.37 & 111 & 120 & 115.50 \\
\hline & Bravo & 46.80 & 60.20 & 53.50 & 2.19 & 2.50 & 2.35 & 185.80 & 138 & 161.90 \\
\hline & A-3127 & 54 & 63.10 & 58.55 & 2.52 & 2.50 & 2.51 & 117.80 & 136 & 126.90 \\
\hline & Arisoy & 48.20 & 78.10 & 63.15 & 2.65 & 2.41 & 2.53 & 89.40 & 130 & 109.70 \\
\hline & Yeşilsoy & 66.04 & 76.23 & 71.14 & 2.36 & 2.53 & 2.45 & 143.92 & 130 & 136.96 \\
\hline & Yemsoy & 50.22 & 50.10 & 50.16 & 2.46 & 2.61 & 2.54 & 178.54 & 190 & 184.27 \\
\hline & Ortalama & $52.21 \mathrm{c}$ & 63.68 a & 57.94 & $2.48 \mathrm{a}$ & $2.56 \mathrm{~b}$ & 2.52 & $124.56 \mathrm{~B}$ & $145 \mathrm{~B}$ & 134.78 B \\
\hline \multirow{10}{*}{$\begin{array}{l}\text { ÇEŞİTLERIN } \\
\text { ORTALAMASI }\end{array}$} & Çeşitler & \multicolumn{3}{|c|}{ Bakla Sayısı (adet/ bitki $^{-1}$ ) } & \multicolumn{3}{|c|}{ Bakla Başına Tohum Sayısı (adet/ bitki ${ }^{-1}$ ) } & \multicolumn{3}{|c|}{ Tohum Verimi (kg/da) } \\
\hline & & 2014 & 2015 & Ort & 2014 & 2015 & Ort & 2014 & 2015 & Ort \\
\hline & Nova & $51.93 \mathbf{E}$ & $60.50 \mathrm{~B}$ & $56.22 \mathrm{D}$ & 2.17 & 2.74 & 2.46 & $105.20 \mathbf{E}$ & $177.33 \mathbf{B}$ & 141.27 B \\
\hline & SA- 88 & $55.67 \mathrm{D}$ & $59.65 \mathrm{BC}$ & $57.66 \mathrm{D}$ & 2.58 & 2.63 & 2.61 & $108.93 \mathbf{D}$ & $140 \mathrm{C}$ & 124.27 E \\
\hline & ATAEM-7 & $63.07 \mathbf{B}$ & $58.53 \mathrm{C}$ & $60.80 \mathrm{C}$ & 2.21 & 2.57 & 2.39 & $111.66 \mathrm{D}$ & $127.33 \mathbf{E}$ & $119.50 \mathrm{~F}$ \\
\hline & Bravo & $47.07 \mathbf{~ F}$ & $58.22 \mathrm{C}$ & $52.65 \mathrm{E}$ & 2.17 & 2.50 & 2.34 & $127.93 \mathrm{C}$ & $130 \mathrm{D}$ & 128.97 D \\
\hline & A-3127 & $53.47 \mathrm{DE}$ & $60.78 \mathrm{~B}$ & 57.13 D & 2.43 & 2.50 & 2.47 & $122.60 \mathrm{C}$ & $138.67 \mathrm{C}$ & 130.64 CD \\
\hline & Arısoy & $57.87 \mathrm{C}$ & $78.30 \mathbf{A}$ & 68.09 B & 2.50 & 2.42 & 2.43 & $112.20 \mathrm{CD}$ & $135.33 \mathrm{C}$ & $123.77 \mathrm{E}$ \\
\hline & Yeşilsoy & $69.45 \mathrm{~A}$ & $79.49 \mathrm{~A}$ & $74.47 \mathrm{~A}$ & 2.47 & 2.53 & 2.50 & $134.78 \mathrm{~B}$ & $134.66 \mathrm{C}$ & $134.72 \mathrm{C}$ \\
\hline & Yemsoy & $51.98 \mathbf{E}$ & $51.80 \mathrm{D}$ & $51.89 \mathrm{E}$ & 2.53 & 2.62 & 2.58 & $193 \mathbf{A}$ & $197 \mathbf{A}$ & $195 \mathrm{~A}$ \\
\hline \multicolumn{2}{|c|}{ Yilların Ortalaması } & 56,31 a & $63.41 \mathrm{~b}$ & 59.86 & 2.39 & 2.29 & 2.28 & 127.04 B & $147.55 \mathrm{~A}$ & 137.30 \\
\hline
\end{tabular}




\begin{tabular}{|c|c|c|c|c|c|c|}
\hline & Bitki Boyu $(\mathrm{cm})$ & Dal Sayıs1 (adet) & İlk Bakla Yüksekliği $(\mathrm{cm})$ & Bakla Sayıs1 (adet/ bitki $\left.{ }^{-1}\right)$ & Bakla Başına Tohum Sayısı (adet/ bitki ${ }^{-1}$ ) & Tohum Verimi $(\mathrm{kg} / \mathrm{da})$ \\
\hline Ç & $* *$ & $* *$ & ös & $* *$ & ös & $* *$ \\
\hline$E$ & $* *$ & ös & ös & ös & ös & $* *$ \\
\hline $\mathrm{Y}$ & ös & ös & ös & $*$ & ös & $* *$ \\
\hline ÇxE & $*$ & $*$ & $*$ & $*$ & $*$ & $* *$ \\
\hline ÇxY & ös & $*$ & ös & $*$ & ös & $* *$ \\
\hline ExY & $*$ & $*$ & ös & $*$ & ös & $* *$ \\
\hline ÇXXXY & $*$ & $*$ & $*$ & $*$ & $*$ & $* *$ \\
\hline
\end{tabular}

Ç:Çeşitler; E:Ekim Zamanı, Y:Yıl, ÇxE: Çeşitler x Ekim Zamanı arasındaki interaksiyon, ÇxY: Çeşitler x Yıllar arasındaki interaksiyon, ExY: Ekim Zamanı xYıllar arasındaki interaksiyon CxExY: Çeşitler x Ekim Zamanı x Yıllar arasındaki interaksiyon ÖS:Önemsiz; *p<0,05, **p<0,01 a,b,c,d,e,f 
Yaptığımız çalışma Doğan vd., 2015'in değerlerinden yüksek çıkarken; Ünal (2007), ve Kınacı (2011)'nın yaptığı çalışmalarla benzerlik göstermektedir. Ancak Yaver ve Paşa (2009)'un çalışmalarından düşük olduğu gözlemlenmiştir. Bakla sayısının yüksek olması istenir, verimle yakın bir ilişki içindedir. Çeşitlerin genetik yapıları ve ekim zamanları bakla sayısını etkilemektedir (Yaver ve Paşa, 2009). Ayrıca yapılan kültürel uygulamaların da (bitki sıklığı, sulama, gübreleme vb.) etki edebileceği düşünülmektedir. Araştırmamızdan elde edilen sonuçlar, iklim özellikleri ve genotipik faktörlerden kaynaklanıyor olabilir.

Bakla başına tohum sayısında çeşitler, ekim zamanları, yıl, çeşit $\mathrm{x}$ yıl, ekim zamanı $\mathrm{x}$ yıl intereaksiyonları arasındaki fark önemsiz bulunurken, çeşit $\mathrm{x}$ ekim zamanı ve çeşit $\mathrm{x}$ ekim zamanı $x$ y1l uygulamas1 interaksiyonları \%5 seviyesinde önemli bulunmuştur (Tablo 3). En yüksek bakla başına tohum sayısı 2014 yılında 2.65 (adet bitki $^{-1}$ ) ile Arısoy çeşidinden, 2015 y1lında ise 2.78 (adet bitki $^{-1}$ ) ile Nova çeşidinden elde edilmiştir. Çeşitler bakımından en yüksek ortalama değer 2.61 (adet bitki $^{-1}$ ) ile SA-88 çeşidinden elde edilmiştir. Ekim zamanı açısından 1 ve 30 Nisan tarihli uygulamalar (2.52 adet bitki ${ }^{1}$ ) en yüksek değerleri vermişlerdir (Tablo 3 ). Baklada tohum sayısı ile ilgili yapılan çalışmalarda, 1.8-3.0 adet ile Karasu vd., (2002); 1.9-2.7 adet ile Sincik vd., (2005); 2.1-2.5 adet ile Y1lmaz vd., (2005); 2-3 adet ile Kinac1 (2011); 1.22.2 adet ile Karagül vd., (2011); 2.6-3.9 adet ile Dolapçı (2012); 2.43-2.78 adet ile de Altınyüzük (2017) farklı sonuçlar elde etmişlerdir. Sonuçlarımız çalışmaların bazıları ile benzerlik gösterirken, diğer çalışmalardan ise düşük veya yüksek bulunmuştur. Bunun sebebinin araştırmaların yürütüldüğü çevre koşulları ile kullanılan çeşitler ve uygulanan kültürel işlemlerden kaynaklandığ düşünülmektedir.

Tohum verimlerine bakıldığında en yüksek verim 2014 ve 2015 y1llarında $202.24 \mathrm{~kg} / \mathrm{da}$ ve $210 \mathrm{~kg} / \mathrm{da}$ ile Yemsoy çeşidinde tespit edilmiştir. Ekim zamanı açısından 1 Nisan tarihli uygulamadan $(143.97 \mathrm{~kg} / \mathrm{da})$ en yüksek değer elde edilmiştir (Tablo 3). Çeşitler, ekim zamanı, y1l, çeşit x ekim zamanı, çeşit $\mathrm{x}$ y1l, ekim zamanı $\mathrm{x}$ yıl ve çeşit $\mathrm{x}$ ekim zaman1 $x$ y1l uygulamas interaksiyonları ise $\% 1$ seviyesinde çok önemli bulunmuştur (Tablo 3). Konuyla yapılan farklı ekim zamanı çalışmalarında tohum veriminde en yüksek değer $371.8(\mathrm{~kg} / \mathrm{da})$ ile Karaaslan vd., (1998)'nin 10 Mayıs tarihli ikinci ekim zamanı uygulamasından; Kara ve Okcu, (2003), dekara $87.3 \mathrm{~kg}$ ile en yüksek tohum verimini 11 Mayıs tarihli ikinci ekim zamanından, Gizlenci vd.,(2005) 416.2 (kg/da) ile ekim zaman1 olarak ikinci uygulaması olan 10 Mayss tarihinden, Çetintaş ve Koç (2005) ise 510 (kg/da) ile 1 Mayıs uygulaması olan ikinci ekim zamanından elde ettiklerini bildirmişlerdir. Elde ettiğimiz sonuçlar, yapılan çalışmaların bazılarından düşük olurken, Kara ve Okcu (2003)'ten yükssek çıkmıştır. Ayrıca Boydak vd., (1998), yapmış oldukları çalışmada en yüksek verimi ilk ekim zamanından elde ettiklerini bildirmişlerdir. $\mathrm{Bu}$ sonuç bizim çalışmamızda da aynı neticeyi vermiş ve en yüksek değer ilk ekim zamanından elde edilmiştir.

Tohum verimi sonuçlarının değişkenlik göstermesinin nedeni, araştırmaların farklı ekolojik koşullarda yapılması ve tespit edilen ekim tarihlerinin özellikle sicaklık açısından lokasyonlardaki değişimden kaynaklanmış olabileceği düşünülmektedir. Kısa gün bitkisi olan soya, verimle ilgili parametreler açısından değişkenlik göstermekte, neticede ayr1 lokasyonlarda yapılan böyle çalışmalarda farklı neticeler ortaya çıkmaktadır. Ayrıca araştırmaların farklı lokasyonlarda yürütülmesi, farklı çeşit kullanımı, uygulanan bakım işlemleri ve iklim koşulları değişikliği ile de farklı durumların ortaya çıkacağı söylenebilir.

\section{Sonuçlar}

Tarla tarımında verim üzerine en fazla etki yapan unsurlardan biri ekim zamanıdır. Soya üretiminde de yaygın bir şekilde kullanılan kültürel uygulamalardan olması ve verimini artırmas bakımından ekim zamanı en önemli uygulamalardan biridir. Ekim zamanı, soyanın gelişim aşamalarını etkileyerek, verim üzerine direk etki yapabilir. Özellikle geç ekim ve olumsuz çevre şartları bunu olumsuz etkilerken, sıcaklık ve fotoperyotta etkileyen faktörlerden birkaçıdır. Vejetasyon peryodu içerisinde geç ekilen soya, vejetatif gelişimini tamamlamak için daha az süreye sahip olacaktır.

Sonuç olarak iki yıl süresince Gümüşhane ili’nde yürütülen bu çalışmada 8 farklı soya çeşidinin 3 farklı ekim zamanı uygulamasına tabi tutularak performansları belirlenmiş, bu bulgular 1şı̆̆ında Yemsoy ve Yeşilsoy çeşitleri en verimli çeşitler oldukları belirlenmiştir. Ekim zamanı açısından ise 1 Nisan tarihli uygulama incelenen parametrelerde en yüksek değerleri vermiştir. 


\section{Teşekkür}

$\mathrm{Bu}$ Araştırma Gümüşhane Üniversitesi Bilimsel Araştırma Projeleri Koordinatörlüğü tarafından (GÜ-BAP) 15.B0123.02.01. proje numarasıla desteklenmiştir. Maddi katkılarından dolayı teşekkür ederim.

\section{Kaynaklar}

Acar, F., 2015. Doğu Geçit Bölgesi Koşullaında Bazı Soya (Glycine max. L) Çeşitlerinin Verim ve Verim Unsurlarının Belirlenmesi.Yüksek Lisans Tezi, Bingöl Üniversitesi Fen Bilimleri Enstitüsü. Bingöl,76s.

Ali, N., 2010. Soybean Processing and Utilization, The Soybean Botany, Production and Uses, Editor", Singh, G., http://www.cabi.org

Altınyüzük, H., 2017. Soya Çeşitlerinin Çukurova Koşullarında II. Ürün Olarak Verim ve Kalite Özelliklerinin İncelenmesi.Yüksek Lisans Tezi,Selçuk Üniversitesi Fen Bilimleri Enstitüsü. Konya,84s.

Bellaloui, N., Hu, Y., Mengistu, A., Kassem, M.A. ve Abel, C.A., 2013. Effects of Foliar Boron Application on Seed Composition, Cell Wall Boron, and Seed $\&^{15} \mathrm{~N}$ and $\&^{13} \mathrm{C}$ Isotopes In Water-Stressed Soybean Plants. Frontiers in Plant Science, 4, 1-12.

Bohn, T., Cuhra, M., Travail, T., Sanden, M., Fagan, J. ve Primicerio, R., 2014. Compositional Differences In Soybeans on The Market: Glyphosate Accumulates in Roundup Ready GM Soybeans. Food Chemistry, 153, 207-215.

Boquet, D.J. ve Clawson, E.L., 2007. Planting Dates For Soybean Varieties in North Louisiana. Ouisiana Agriculture Magazine, LSUA, www.lsuacenter.com/portals/communications/ publications/agmag/archve/2007.

Boydak, E., Kayantaş, B., Acar, F. ve Fırat, R., 2018. Bazı Soya Fasulyesi (Glycine max. L) Çeşitlerinin Yüksek Rakımlarda Verim ve Verim Unsurlarının Belirlenmesi. Harran Tarım ve G1da Bilimleri Dergisi, 22(4), 544550.

Boydak, E., İşler, N. ve Karaarslan, D., 1998. Harran Ovası Şartlarında II. Ürün Soyanın (Glycine $\max$ L.) En Uygun Ekim Zamanının Belirlenmesi. Harran Üniversitesi Ziraat Fakültesi Dergisi, 2(1), 25-34.

Calvino, P.A., Sadras, V.O. ve Andrade, F.H., 2003a. Quantification of Environmental and Management Effects on The Yield of LateSown Soybean. Field Crops Research, 83, 6777.
Calvino, P.A., Sadras, V.O. ve Andrade, F.H., 2003 b. Development, Growth and Yield of Late-Sown Soybean in the Southern Pampas. European Journal of Agronomy. 19, 265-275.

Chen, G.H. ve Wiatrak, P. 2010. Soybean Development and Yield Are Influenced By Planting Date and Environmental Conditions In Southeastern Coastal Plan, United States. Agronomy Journal. 102, 1731-1737.

Çetintaş, Z. ve Koç, H., 1993. Tokat Yöresinde Farklı Ekim Zamanlarının Farklı Soya (Glycine max (L.) Merrîl) Çeşitlerinin Verim ve Kalitesine Etkileri Üzerinde Araştırmalar. Gaziosmanpaşa Üniversitesi Ziraat Fakültesi Dergisi, 10, 193-201.

Dolapç1, F., 2012, Kahramanmaraş Ekolojik Koşullarında Bazı Soya Çeşitlerinin Tohum ve Yağ Verimi ile Verim Unsurlarını Belirlemek Amacı ile Yürütülen Çalışma. Yüksek Lisans Tezi, Kahramanmaraş Sütçü İmam Üniversitesi Fen Bilimleri Enstitüsü, Kahramanmaraş,61s.

Doğan, Y., Koyutürk, Ö. ve Aktaş, H., 2015. MardinKızıltepe Ekolojik Koşullarında Ekim Zamanı Uygulamalarının Bazı Soya Fasulyesi (Glycine max. L.) Çeşitlerinde Verim ve Verim Öğeleri Üzerine Etkisi. Y.Y.Ü. Tarım Bilimleri Dergisi.25(3), 293-303.

Erdoğmuş, M., Arslan, D. ve Olgun, H., 2007. Bazı Soya Çeşitlerinin Organik ve Geleneksel Yetiştirme Sistemlerinde Performanslarının Karşılaştırılması. 28-31 Mayıs 2007, 1.Ulusal Yağlı Tohumlu Bitkiler ve Biyodizel Sempozyumu, Poster Bildiriler Kitabı (editörler:H.Özcan,M.Durmuş)439-442. Samsun.

Ghodrati, G.R., Sekhavat, R. ve Gholami, A., 2013. Evaluation of Correlations and Path Analysis of Components Seed Yield in Soybean. International Journal of Agriculture, 3, 795800 .

Gizlenci, Ş., Üstün, A., Acar, M., Dok, M. ve Aygün, Y., 2005. Orta Karadeniz Sahil Kuşağında Orta Erkenci ve Erkenci Soya İçin En Uygun Ekim Zamanının Belirlenmesi. 5-9 Eylül 2005, Türkiye IV. Tarla Bitkileri Kongresi, 381-386, Antalya.

Han, T.F., C.X. Wu, Z. Tong, R.S. Mentreddy, K.H. Tan ve Gai, J.Y., 2006. Post Flowering Photoperiod Regulates Vegetative Growth and Reproductive Development of Soybean. Environmental and Experimental Botany.55, 120-129.

Hoeft, R.G., Aldrich, S.R., Nafziger, E.D., Johnson, R.R., 2000. Modern Corn and Soybean 
Production. Publisher: Champaign, III:MCSP Publications, 1 st ed.353p.

Hu, M.ve Wiatrak, P., 2012. Effect of Planting Date on Soybean Growth, Yield, and Grain Quality: Review. Agronomy Journal., 104, 785-790.

İlisulu, K., 1973. Yağ Bitkileri ve Islahı: Ankara, Çağlayan Kitabevi, 195-199.

Kang, B-K., H-T. Kim, M-S. Choi, S-C. Koo, J-H. Seo, H-S. Kim, S-O. Shin, H-T. Yun, I-S. Oh, K.P. Kulkarni ve J.D. 55 Lee. 2017. Genetic and Environmental Variation of First Pod Height in Soybean [Glycine $\max$ (L.) Merr.]. Plant Breeding Biotechnology. 5(1):36 44. https://doi.org/10.9787/PBB.2017.5.1.36.

Kara, K. ve Okçu, M., 2003. Erzurum Şartlarında Soyanın Farklı Olgunlaşma Dönemlerinde Hasadının Ot Verim ve Kalitesi Üzerine Etkileri, Türkiye 5. Tarla Bitkileri Kongresi, Ekim 2003, Diyarbakır, Türkiye, s. 649-654.

Karaaslan, D., Boydak, E. ve Gür, M.A., 1998. Farklı Ekim Zamanlarının Bazı Soya Fasulyesi (Glycine $\max$ L.) Çeşitlerinde Verim ve Verim Komponentlerine Etkisi. Harran Üniversitesi Ziraat Fakültesi Dergisi, 2(4), 55-64.

Karagül, E.T., Ay, N., Nazlıcan, N.A. ve Demircioğlu, M.C., 2011. Ege Bölgesi İkinci Ürün Koşullarında Bazı Soya Fasulyesi (Glycine Max L. Merr.) Genotiplerinin Verim ve Kalite Özelliklerinin Belirlenmesi, 12-15 Eylül 2011,Türkiye 9.Tarla Bitkileri Kongresi, Cilt II, 1057-1062. Bursa.

Karasu, A., Öz, M. ve Göksoy, A. T., 2002. Bazı Soya Fasulyesi [Glycine max (L.) Merill] Çeşitlerinin Bursa Koşullarına Adaptasyonu Konusunda Bir Çalışma. Uludağ Üniversitesi Ziraat Fakültesi Dergisi, 16(2), 25-34.

Kınacı, M., 2011. Çanakkale Koşullarında Soya Fasulyesi Çeşitlerinin Verim Bazı Kalite Unsurlarının Belirlenmesi. Yüksek Lisans Tezi, Selçuk Üniversitesi Fen Bilimleri Enstitüsü, Konya,76s.

Kumudini, S.V., Pallikonda, P.K. ve Steele, C., 2007. Photoperiod and E-Genes Influence The Duration of The Reproductive Phase in Soybean. Crop Science, 47, 1510-1517.

Naeve, S.L., Potter, B.D., Quiring, S.R., O’Neil, T.A. ve Kurle, J.E., 2004. Influence of Soybean Plant and Population and Row Spacing On Development and Yield Across Planting Dates in Minnesota, www.soybeans.umn.edu/pdfs/2004asaposter_ 1_spacingplanting_screen.pdf.
Ngalamu, T., Meseka, S. ve Ashraf, M., 2012. Performance of Soybean (Glycine max. L. Merill) Genotypes Under Different Planting Dates in Sennar State of The Sudan. Journal of Applied Biosciences, 49, 3363-3370.

Okcu, M., Tozlu, E., Pehluvan, M., Kaya, C., Kumlay, M. ve Dizikısa, T., 2007. Erzurum- Pasinler Ekolojik Şartlarında Farklı Soya Fasulyesi (Glycine max L.) Çeşitlerinin Uyumu Üzerine Bir Araştırma, 28-31 Mayıs 2007.1. Ulusal Yağlı Tohumlu Bitkiler ve Biyodizel Sempozyumu, Sunulu Bildiriler Kitab1 (editörler:H.Özcan,M.Durmuş),219-224. Samsun.

Oz, M., Karasu, A., Goksoy, T.A. ve Turan, M., 2009. Interrelationships of Agronomical Characteristics in Soybean (Glycine max) Grown in Different Environments. International Journal of Agriculture \& Biology, 11(1), 85-88.

Rahman, M.M., Hampton, J.G. ve Hill, M.J. 2005. Soybean Seed Yield As Affected By Time of Sowing in A Cool Temperature Environment. Seed Science Technology, 7, 1-15.

Ram, H., Singh, G. ve Aggarwal, N., 2010. Effect of Time of Sowing on The Performance of Soybean [Glycine Max (L.) Merrill] In Punjab. Journal Research Punjab Agric Univ 47 (3 \& 4): 127-31, Sep. \& Dec. 2010

Ramteke, R., Singh, D. ve Murlidharan, P., 2012. Selecting Soybean (Glycine Max) Genotypes For Insertion Height of The Lowest Pod, The Useful Trait For Combine Harvester. Indian Journal of Agricultural Sciences 82(6), 511515 .

Rehman, M., Khaliq, T., Ahmad, A., Wajid, S.A., Rasul, F., Hussain, J. ve Hussain, S., 2014. Effect of Planting Time and Cultivar on Soybean Performance in Semi-Arid Punjab, Pakistan. Global Journal of Science Frontier Research: D Agriculture and Veterinary, 14(3), 41-45.

Robinson, A.P., Conley, S.P., Volenec, J.J. ve Santini, J.B., 2009. Analaysis of High Yielding, EarlyPlanted Soybean in India. Agronomy Journal, 101, 131-139.

Sadeghi, S.M. ve Niyaki, S.A., 2013. Effects of Planting Date and Cultivar on The Yield and Yield Components of Soybean in North of Iran. ARPN Journal of Agricultural and Biological Science, 8(1), 81-85.

Sezen, Y., 1991. Gübreler ve Gübreleme: Erzurum, Atatürk Üniversitesi Ziraat Fakültesi Yayınları No: 679, s. 39-96. 
Sincik, M., Göksoy, A. T. ve Turan, Z. M., 2005. Bursa Koşullarında Bazı Soya (Glycine max (L.) Merill) Çeşitlerinin Verim ve Verim Öğelerinin Belirlenmesi Üzerine Bir Araştırma, 5-9 Eylül 2005.Türkiye VI. Tarla Bitkileri Kongresi, (Araştırma Sunusu II), Antalya, 1095-1099.

Ünal, İ., 2007. Melezleme Yöntemiyle Elde Edilen Soya [Glycine max (L.) Merr.] Hatlarının Bazı Tarımsal Özelliklerinin Belirlenmesi. Yüksek Lisans Tezi, Selçuk Üniversitesi Fen Bilimleri Enstitüsü, Konya, 60s.

Wade, F.F. ve Johnston T.H., 1975. Effect of Seeding Date on Growth And Performance of Rice in Arkansas. Agricultural Experiment Station University of Arkansas, Report Series, Arkansas, 224p.

Whigham, D.K. ve Minor, H.C., 1978. Agronomic Characteristics and Environmental Stress, Soybean Agronomy, Physiology, and Utilization: London, Academic Press, 247p.
Yaver, S. ve Paşa, C., 2009. Tekirdağ Koşullarında Bazı Soya Fasulyesi Çeşitlerinin Verim Kriterleri Üzerine Bir Araştırma,19-22 Ekim 2009. Türkiye VIII. Tarla Bitkileri Kongresi, Hatay, 197-200.

Yıldız, N. ve Bircan, H., 1994. Araştırma ve Deneme Metodlar1. Atatürk Üniversitesi No: 697, Ziraat Fakültesi No: 305, Ders Kitabı No: 57, Erzurum. 277 s.

Yılmaz, A., Beyyavaş, V., Cevheri, İ. ve Haliloğlu, H., 2005, Harran Ovası Ekolojisinde İkinci Ürün Olarak Yetiştirilebilecek Bazı Soya (Glycine max. L. Merrill.) Çeşit ve Genotiplerinin Belirlenmesi, HÜ Ziraat Fakültesi Dergisi, 9(2), 55-61.

Zhang, Qiu-ying., Qing-lu Gao, S.J., Herbert, Yansheng Li ve Hashemi, A.M. 2010. Influence of Sowing Date on Phenological Stages, Seed Growth And Marketable Yield of Four Vegetable Soybean Cultivars in North-Eastern USA. African Journal Agriculture Research, 5(18), 2556-2562. 